\title{
Age- and Sex-Related Profiles of Serum Primary and Total Bile Acids in Infants, Ghildren and Adults
}

\author{
Hironaka Kawasaki, Yasuhito Yamanishi, ${ }^{*}$ Mariko \\ Miyake, $†$ Tetsuo Mura $\dagger$ and Shiro Ikawa $\dagger$ \\ The Second Department of Internal Medicine and $\dagger$ Division \\ of Chemistry, Institute of Steroid Research, Tottori \\ University School of Medicine, Yonago 683 and *Tanabe \\ National Hospital, Tanabe, Wakayama 646
}

\begin{abstract}
Kawasaki, H., Yamanishi, Y., Mryake, M., Mura, T. and Inawa, S. Ageand Sex-Related Profiles of Serum Primary and Total Bile Acids in Infants, Children and Adults. Tohoku J. exp. Med., 1986, $150(3), 353-357$ - The relation of age and sex to serum primary (PBA) and total bile acid (TBA) concentrations was evaluated by an enzymatic fluorometric microassay in healthy infants, children and adults. TBA concentrations were the highest in the 6-dayold group and 1-month-old group and seemed to switch to almost normal adult levels by the age of 4-6 years, which persisted throughout life, while PBA concentrations were predominant over a period of 3 days to 3 months after birth. No sex-related differences were observed from neonates to very old persons for any of serum bile acids. These results show that the bile acid metabolism in the liver and the enterohepatic circulation of bile acids are usually matured in infancy and that aging and sex may insignificantly affect serum bile acid metabolic profiles. age ; sex; primary bile acids; total bile acids
\end{abstract}

It has recently been recognized that serum bile acid levels are sensitive indicators of hepatobiliary disease and are useful as one of reliable liver function tests. However, serum bile acid levels are dependent upon several factors, i.e., hepatic synthesis and elimination of bile acids, intestinal motility and absorption, gallbladder function and renal elimination of bile acids. So far age-related changes of serum bile acids have been reported by several earlier workers with different methods of bile acid assay (Sandberg 1970; Barbara et al. 1980; Heikura et al. 1980; Arisaka 1981; Suchy et al. 1981), but the information available was highly fragmentary. The changes of serum bile acids in healthy subjects with a wide range of age from the neonatal period to the elderly have not yet been fully studied. Establishment of normal levels of serum bile acids in the age groups from neonates to the very elderly is important for the understanding of pathophysiological changes of bile acid metabolism, especially for the detection of hepatobiliary diseases and bile acid malabsorption. The present study

Received September 9, 1986 ; accepted for publication October 27, 1986. 
examined the relationship of age and sex to serum primary (PBA) or total bile acid (TBA) concentrations in a large population of normal infants, children and adults by an enzymatic fluorometric microassay (Ikawa et al. 1985) which has a high sensitivity and precision with the use of a small volume of serum.

\section{Materials and Methods}

The subjects of the present study were 19 infants (10 males and 9 females) whose age ranged from one day to six days after birth and 69 infants and children ( 37 males and 32 females) who were at the ages of $1,2,3$ and 5 months and $1,2,3,4-6,7-9$ and $10-15$ years as shown in detail in Table 1. All infants and children were clinically well at the time of study. Moreover, the present determinations were also made on a total of 170 adults (74 males and 96 females). Their liver function tests were normal, as evaluated by the levels of serum bilirubin, SGOT, SGPT, alkaline phosphatase, albumin, gamma globulin and prothrombin and none of the subjects had any evidence of gastrointestinal and hepatobiliary diseases. Informed consent was obtained from the parents of all infants and children and each adult in this study. Blood samples were obtained $3 \mathrm{hr}$ after the last feeding in infants by heel puncture up to the age of 6 days after birth and from the peripheral vein at the ages of 1-5 months and also from the antecubital vein of children and adults after an overnight fast. Each serum sample was kept frozen at $-20^{\circ} \mathrm{C}$ until analysis.

Serum concentrations of PBA and TBA were measured in each serum by an enzymatic fluorometric microassay described previously (Ikawa et al. 1985).

Results are expressed as mean \pm S.D. Statistical analysis was carried out using Student'

TABle 1. Serum primary and total bile acids and $P / T$ ratio in infants and children

\begin{tabular}{ccccc}
\hline & \multirow{2}{*}{$\begin{array}{c}\text { Number } \\
\text { Age }\end{array}$} & \multicolumn{2}{c}{ Serum bile acid $(\mu \mathrm{M})$} & \multirow{2}{*}{ P/T ratio $(\%)$} \\
\cline { 3 - 4 } & cases & Primary & Total & \\
\hline 1 day & 19 & $11.7 \pm 4.9$ & $17.6 \pm 6.5$ & $66.1 \pm 8.6$ \\
2 days & 19 & $14.5 \pm 6.5$ & $18.9 \pm 7.9$ & $81.6 \pm 9.9^{* *}$ \\
3 days & 19 & $16.6 \pm 7.0^{*}$ & $19.9 \pm 8.5$ & $82.9 \pm 8.4^{* *}$ \\
4 days & 19 & $21.4 \pm 7.7^{* *}$ & $24.0 \pm 9.4^{*}$ & $88.0 \pm 7.8^{* *}$ \\
5 days & 19 & $21.9 \pm 6.6^{* *}$ & $23.9 \pm 6.8^{* *}$ & $90.9 \pm 3.9^{* *}$ \\
6 days & 19 & $24.3 \pm 9.1^{* *}$ & $27.1 \pm 8.6^{* *}$ & $91.5 \pm 3.6^{* *}$ \\
1 month & 4 & $24.7 \pm 9.4^{* *}$ & $27.1 \pm 10.0^{*}$ & $91.2 \pm 1.1^{* *}$ \\
2 months & 5 & $22.8 \pm 8.3^{* *}$ & $25.2 \pm 9.4$ & $91.1 \pm 1.3^{* *}$ \\
3 months & 4 & $20.2 \pm 6.1^{* *}$ & $22.6 \pm 6.6$ & $89.3 \pm 2.4^{* *}$ \\
5 months & 3 & $15.0 \pm 6.7$ & $17.0 \pm 7.3$ & $87.5 \pm 2.5^{* *}$ \\
1 year & 9 & $10.8 \pm 3.5$ & $15.3 \pm 4.6$ & $70.8 \pm 2.9$ \\
2 years & 10 & $8.1 \pm 2.6$ & $12.0 \pm 3.9$ & $67.9 \pm 1.1$ \\
3 years & 9 & $8.7 \pm 2.2$ & $13.5 \pm 3.4$ & $64.3 \pm 2.1$ \\
$4-6$ years & 5 & $4.1 \pm 1.3$ & $6.3 \pm 1.8$ & $65.5 \pm 4.8$ \\
$7-9$ years & 5 & $3.2 \pm 1.1$ & $4.8 \pm 1.4$ & $65.1 \pm 4.6$ \\
$10-15$ years & 15 & $2.9 \pm 1.0$ & $4.4 \pm 1.4$ & $66.1 \pm 4.6$ \\
\hline
\end{tabular}

Values represent mean \pm S.D.

Statistically significant differences $\left({ }^{*} p<0.05,{ }^{* *} p<0.01\right)$ in comparison with values on 1 day. 
TABLE 2. Serum primary and total bile acids and $P / T$ ratio in adults

\begin{tabular}{|c|c|c|c|c|c|}
\hline \multirow{2}{*}{ Sex } & \multirow{2}{*}{$\begin{array}{c}\text { Age range } \\
\text { (year) }\end{array}$} & \multirow{2}{*}{$\begin{array}{c}\text { Number } \\
\text { of } \\
\text { cases }\end{array}$} & \multicolumn{2}{|c|}{ Serum bile acid $(\mu \mathrm{M})$} & \multirow{2}{*}{$\mathrm{P} / \mathrm{T}$ ratio $(\%)$} \\
\hline & & & Primary & Total & \\
\hline \multirow{5}{*}{ Male } & $16-29$ & 20 & $3.0 \pm 1.2$ & $4.9 \pm 1.8$ & $62.0 \pm 6.8$ \\
\hline & $30-49$ & 26 & $2.7 \pm 1.5$ & $4.2 \pm 2.2$ & $65.1 \pm 9.3$ \\
\hline & $50-69$ & 24 & $2.9 \pm 1.1$ & $4.2 \pm 1.7$ & $67.4 \pm 9.3$ \\
\hline & $70-79$ & 4 & $2.8 \pm 0.2$ & $4.5 \pm 0.6$ & $61.8 \pm 3.9$ \\
\hline & Total & 74 & $2.9 \pm 1.3$ & $4.4 \pm 1.9$ & $65.0 \pm 8.7$ \\
\hline \multirow{5}{*}{ Female } & $16-29$ & 18 & $2.7 \pm 1.4$ & $4.4 \pm 1.6$ & $60.7 \pm 11.7$ \\
\hline & $30-49$ & 21 & $2.7 \pm 1.3$ & $4.3 \pm 1.9$ & $63.8 \pm 9.1$ \\
\hline & $50-69$ & 43 & $2.7 \pm 1.2$ & $4.3 \pm 1.9$ & $64.3 \pm 9.1$ \\
\hline & $70-84$ & 14 & $3.0 \pm 1.2$ & $4.7 \pm 1.8$ & $65.2 \pm 11.5$ \\
\hline & Total & 96 & $2.8 \pm 1.2$ & $4.4 \pm 1.8$ & $63.7 \pm 9.9$ \\
\hline \multicolumn{2}{|c|}{ Male + Female } & 170 & $2.8 \pm 1.2$ & $4.4 \pm 1.9$ & $64.2 \pm 9.4$ \\
\hline
\end{tabular}

Values represent mean \pm s.D.

s $t$-test. Correlation coefficients were obstained by the linear regression analysis.

\section{Results}

Table 1 shows the mean concentrations of $\mathrm{PBA}$ and TBA and $\mathrm{P} / \mathrm{T}$ ratios in the various age groups in infants and children. The mean concentrations of PBA and TBA and the ratio of serum primary bile acids to total bile acids ( $\mathrm{P} / \mathrm{T}$ ratio) at the age of 1 day were $11.7 \pm 4.9 \mu \mathrm{M}, 17.6 \pm 6.5 \mu \mathrm{M}$ and $66.1 \pm 8.6 \%$, respectively. The serum concentration of both bile acids increased gradually but significantly with peak levels occurring at the age of 1 month, showing a predominant PBA in the sera of infants by the age of 3 months and a significant increase in $\mathrm{P} / \mathrm{T}$ ratio by the age of 5 months, which then declined to nearly the adult levels by the age of 4-6 years. No sex-related differences were observed in both bile acids and $\mathrm{P} /$ $\mathrm{T}$ ratio of infants and children. Linear regression analysis demonstrated a significant positive correlation between the postnatal age up to 6 days and the serum concentration of PBA $(r=0.98, p<0.01)$, TBA $(r=0.97, p<0.01)$ and $\mathrm{P} /$ $\mathrm{T}$ ratio $(r=0.98, p<0.01)$. Moreover, the postnatal age from 1 month to 3 years correlated inversely with the serum concentration of PBA $(r=-0.67, p<0.01)$, TBA $(r=-0.56, p<0.01)$ and $\mathrm{P} / \mathrm{T}$ ratio $(r=-0.89, p<0.01)$.

Serum concentrations of $\mathrm{PBA}, \mathrm{TBA}$ and $\mathrm{P} / \mathrm{T}$ ratios for males and females in adults are presented in Table 2 . The mean concentrations of PBA and TBA and $\mathrm{P} / \mathrm{T}$ ratios in 74 males were $2.9 \pm 1.3 \mu \mathrm{M}, 4.4 \pm 1.9 \mu \mathrm{M}$ and $65.0 \pm 8.7 \%$, respectively, whereas those in 96 females were $2.8 \pm 1.2 \mu \mathrm{M}, 4.4 \pm 1.8 \mu \mathrm{M}$ and $63.7 \pm 9.9 \%$, respectively. No difference could be demonstrated between males and females. 
When compared with serum concentrations of both bile acids and $\mathrm{P} / \mathrm{T}$ ratios in adults at the ages of 16-29, 30-49, 50-69 and 70 years and above, no age- and sex-related differences could be observed for $\mathrm{PBA}$, TBA or $\mathrm{P} / \mathrm{T}$ ratio.

\section{Discussion}

Recently, serum bile acids have been simply measured by an enzymatic fluorometric method using $3 \alpha$-hydroxysteroid dehydrogenase. The present enzymatic fluorometric microassay using a small volume of serum was developed based on a modified method of Barnes and Spenney (1980) and showed a high sensitivity and precision (Ikawa et al. 1985). Serum bile acid levels during the fasting state are mainly dependent upon hepatic and intestinal handling of bile acids. Aging usually implies a decline in physiological function. However, the influence of aging on serum bile acid levels has not been fully studied, though synthesis of bile acids is decreased in elderly persons, possibly related to reduced cholic acid pool size (Einarsson et al. 1985). The main purpose of the present study was to establish pediatric and adult normal levels of PBA and TBA assayed by the enzymatic fluorometric method often used for clinical determination of bile acids.

In the present study, $\mathrm{PBA}, \mathrm{TBA}$ and $\mathrm{P} / \mathrm{T}$ ratio in infants peaked between 6 days and one month after birth which gradually decreased with age to 3 years of age and then seemed to switch to adult levels from 4 to 6 years of age. By a specific radioimmunoassay, the concentrations of $\mathrm{PBA}$ were significantly higher in the serum of 1-hour old infants than those in the umbilical cord serum or the peripheral vein serum in adults and the peak level was reached between 7 days and 1 month (Heikura et al. 1980) or in the first year (Barbara et al. 1980; Arisaka 1981 ; Suchy et al. 1981) after birth. These findings which suggested a physiologic cholestasis in infants may be a reflection of the immaturity of the liver in handling bile acids.

Earlier studies have partially included healthy subjects as old as those in our study (Murphy et al. 1970; Schwarz et al. 1974; Mashige et al. 1976 ; Shaffer and Gordon 1978; Starkey and Marks 1982). When the correlation of age to serum bile acid levels in a large proportion of healthy adults was studied by the enzymatic fluorometric method, no age-related differences were observed for PBA, TBA and $\mathrm{P} / \mathrm{T}$ ratio which reflects the conditions of intestinal microflora and serum bile acid levels in adults were maintained at nearly normal levels even at very advanced age.

Serum bile acid levels were not affected by sex (Schwarz et al. 1974 ; Shaffer and Gordon 1978; Barbara et al. 1980; Starkey and Marks 1982), whereas the levels are slightly high in females (Murphy et al. 1970) or in males (Mashige et al. 1976). The results of the present study indicated that no sex-related differences could be observed statistically for any of serum bile acids in all age groups, suggesting that age and sex insignificantly affect bile acid metabolic profiles in 
healthy adults as far as serum bile acids are concerned and serum bile acid determinations are clinically useful as a liver function test in a wide range of age.

\section{Acknowledgments}

This study was partly supported by Grant for Scientific Research No. 60570321 from the Ministry of Education, Science and Culture, Japan.

\section{References}

1) Arisaka, O. (1981) Studies on the enterohepatic circulation of bile acids in infancy and childhood. Acta paediat. jap., 23, 341-352.

2) Barbara, L., Lazzari, R., Roda, A., Aldini, R., Festi, D., Sama, C., Morselli, A.M., Collina, A., Bazzoli, F., Mazzella, G. \& Roda, E. (1980) Serum bile acids in newborns and children. Pediat. Res., 14, 1222-1225.

3) Barnes, S. \& Spenney, J.G. (1980) Improved enzymatic assays for bile acids using resazurin and NADH oxidoreductase from Clostridium Kluyveri. Clin. chim. Acta, 102, 241-245.

4) Einarsson, K., Nilsell, K., Leijd, B. \& Angelin, B. (1985) Influence of age on secretion of cholesterol and synthesis of bile acids by the liver. New Engl. J. Med., 313, 277282.

5) Heikura, S., Similä, S., Finni, K., Mäentausta, O. \& Jänne, O. (1980) Cholic acid and chenodeoxycholic acid concentrations in serum during infancy and childhood. Acta paediat. scand., 69, 659-662.

6) Ikawa, S., Kawasaki, H., Yamanishi, Y., Mura, T. \& Miyake, M. (1985) Measurement of the ratio of primary to total bile acids in serum by enzymatic fluorometric microassay and its clinical significance in patients with liver disease. Tohoku J. exp. Med., 145, 185-195.

7) Mashige, F., Imai, K. \& Osuga, T. (1976) A simple and sensitive assay of total serum bile acids. Clin. chim. Acta, 70, 79-86.

8) Murphy, G.M., Billing, B.H. \& Baron, D.N. (1970) A fluorometric and enzymatic method for the estimation of serum total bile acids. J. clin. Path., 23, 594-598.

9) Sandberg, D.H. (1970) Bile acid concentrations in serum during infancy and childhood. Pediat. Res., 4, 262-267.

10) Schwarz, H.P., Bergmann, K. \& Paumgartner G. (1974) A simple method for the estimation of bile acids in serum. Clin. chim. Acta, 50, 197-206.

11) Shaffer, E.A. \& Gordon, E.R. (1978) Serum bile acids as related to bile acid secretion in liver disease. Amer. J. dig. Dis., 23, 392-397.

12) Starkey, B.J. \& Marks, V. (1982) Determination of total bile acids in serum. A comparison of a radioimmunoassay with an enzymatic-fluorimetric method. Clin. chim. Acta, 119, 165-177.

13) Suchy, F.J., Balistreri, W.F., Heubi, J.E., Searcy, J.E. \& Levin, R.S. (1981) Physiologic cholestasis: Elevation of the primary serum bile acid concentrations in normal infants. Gastroenterology, 80, 1037-1041. 